Yu. S. MASLII ${ }^{1}$ (https://orcid.org/0000-0002-8968-0262),

O. O. HRUDNYTSKA ${ }^{2}$ (https://orcid.org/0000-0002-8297-7119),

O. A. RUBAN ${ }^{1}$ (https://orcid.org/0000-0002-2456-8210),

G. V. ZAYCHENKO ${ }^{2}$ (https://orcid.org/ 0000-0002-3506-4800)

${ }^{1}$ National University of Pharmacy, Kharkiv

${ }^{2}$ Bogomolets National Medical University, Kyiv

\title{
JUSTIFICATION OF LOCAL ANESTHETIC AND CHOICE OF ITS CONCENTRATION IN COMPOSITION OF DENTAL GEL
}

Key words: dental gel, lidocaine hydrochloride, local anesthetic activity

Ю. С. МАСЛІЙ ${ }^{1}$ (https://orcid.org/0000-0002-8968-0262), канд. фарм. наук, доцент,

О. О. ГРУДНИЦЬКА ${ }^{2}$ (https://orcid.org/0000-0002-8297-7119),

О. А. РУБАН ${ }^{1}$ (https://orcid.org/0000-0002-2456-8210), д-р фарм. наук, проф.,

Г. В. ЗАЙЧЕНКО ${ }^{2}$ (https://orcid.org/ 0000-0002-3506-4800), д-р мед. наук, проф.

${ }^{1}$ Наиіональний фармацевтичний університет, м. Харків

${ }^{2}$ Національний медичний університет імені О. О. Богомольия, м. Київ

ОБГРРУНТУВАННЯ АНЕСТЕТИКА МІСЦЕВОЇ ДІЇ ТА ВИБІР ЙОГО

КОНЦЕНТРАЦІї У СКЛАДІ СТОМАТОЛОГІЧНОГО ГЕЛЮ

Ключові слова: стоматологічний гель, лідокаїну гідрохлорид, місцевоанестезуюча активність

One of the most urgent problems of modern dentistry is inflammatory diseases of the periodontis, oral mucosa, and also similar in etiology pathologies that arise when using dentures of various designs $[1,2]$. For the treatment of the aforementioned diseases, an application method is traditionally used in dental practice, which is to apply drugs to the surface of the gums or oral mucosa [3].

Often, dental diseases are accompanied by pain, so usually symptomatic treatment of these pathologies includes analgesics [3, 4]. In dental practice, various dosage forms (DF) containing local anesthetics are used - solutions, ointments, gels, aerosols, films [4, 5]. Dental gels have been widely used, since they are well distributed and prolonged on the surface of the mucous membranes, they can cause local anesthetic effect and keep it for a certain time [6].

For the purpose of surface anesthesia most often used are dicaine, pyrimecane, benzocaine (anestezin) and lidocaine [7, 8]. Based on the literature data, we had selected an anesthetic of local action - lidocaine hydrochloride, which has a pronounced local anesthetic effect, quickly penetrates the surface of the mucosa, causing blockade of nociceptors and sensitive peripheral nerve fibers. It is available in various topical DF, in particular in the form of gel, solution, ointment and spray $[9,10]$. In the pharmaceutical market of Ukraine, for the treatment of periodontal disease and mucosal lesions among the registered drugs in the form of dental gel with lidocaine hydrochloride at a concentration of $2.0 \%$, there are "Kamistad ${ }^{\mathbb{B} " ~(S t a d a ~ A r z n e i m i t t e l ~ A G, ~ G e r m a n y) ~ a n d ~ " C a m i d e n t-H e a l t h " ~(L L C ~ " P C ~}$ Health", Ukraine) $[11,12]$. Children's dental anesthetic gels to interfere the pain in teeth erosion are also known, for example, "Dentinox-gel H" (Dentinox Gesellschaft fur, Pharmazeutische Praparate Lenk \& Schuppan, Germany) containing lidocaine hydrochloride at a concentration of $0.32 \%$ [12].

The dental gel, which is being developed at the NUPh's Department of Industrial Technology of Drugs, contains in addition to lidocaine hydrochloride (Societa Italiana Medicinali Scandicci, Italy), tincture "Phytodent" (PJSC “CPP" Red Star", Ukraine) and choline salicylate $80 \%$ (Basf Pharma, Switzerland). Their concentrations were chosen on the basis of microbiological studies. The gelling agent is Carbomer Polacril ${ }^{\circledR} 40 \mathrm{P}$ (Amedeo Brasca \& C. Srl, Italy) [6].

(C) Колектив авторів, 2019 
The aim of our work is to determine the optimal concentration of lidocaine hydrochloride in the composition of the dental gel, which is developed for the treatment of inflammatory diseases of the periodontium and oral mucosa.

\section{Mat e rials a nd methods}

The object of our research was a dental gel containing different amounts of lidocaine hydrochloride $-1.0 \%, 1.5 \%$ and $2.0 \%$. As a reference drug, the gel "Kamistad" ${ }^{\circledR} "$ (Stada Arzneimittel AG, Germany) was used.

Studying local anesthetic/analgesic activity of the gel was carried out by Randall-Selitto method using electronic Pressure Analgesiometer (Almemo ${ }^{\circledR}$ ) [13]. The study was conducted on male rats of the Wistar line weighing 190-210 g. 20 animals were selected and divided into 4 groups, each of 5 rats. Animals were on a standard diet and under standard vivarium conditions of the O. O. Bogomolets National Medical University, in accordance with the sanitary-hygienic conditions. An animal from each group was immobilized in the hands of the researcher, its limb was placed in analgesiometer. The force of pressure in grams was determined, which causes the reaction of the detachment of the paw/squeal in response to the pain stimulus. Thus, the initial sensitivity level was measured.

Analgesic activity was studied on the model of kaolin edema, as a model with the most pronounced pain component [13]. Kaolin edema was modeled by sub-planar introduction of kaolin solution $(10 \mathrm{mg} / \mathrm{ml})$ to rats in an amount of $0.1 \mathrm{ml} / 100$ grams of body weight (administration under the aponeurosis of the posterior paw).

Next, the animals were evaluated for baseline pain sensitivity 1 hour after the introduction of the phlogogenic agent, after which the gel was applied to the foot, and after 1 hour 15 minutes, 1 hour 30 minutes and 2 hours after the exudative edema modeling. Calculated the percentage change to the initial threshold of tactile sensitivity, as well as the percentage change to the level of algesia (pain response) 1 hour after the introduction of the phlogogenic agent.

The antinociceptive (analgesic) effect of the test samples on the model of inflammatory hyperanalgesia was also evaluated by the pain sensitivity threshold (PST) during the development of the most severe pain during the period from 60 to 120 minutes after the introduction of kaolin. The analgesic activity (AA) was calculated according to the following formula:

$$
\mathrm{AA}=\frac{\mathrm{PST}_{\mathrm{e}}-\mathrm{PST}_{\mathrm{c}}}{\mathrm{PST}_{\mathrm{c}}} \times 100,
$$

where $\mathrm{PST}_{\mathrm{e}}$ - PST in animals of the experimental group;

$\mathrm{PST}_{\mathrm{c}}-\mathrm{PST}$ in animals of the control group.

All animal intervention and euthanasia were carried out in accordance with "The provisions of the European Union Directive 2010/63/EU on the protection of animals used for scientific purposes" [14] and also in accordance with the "General Ethical Principles of Animal Experiments" adopted by the First National Congress on Bioethics (Kyiv, 2001) and the Law of Ukraine "On Protection of Animals from Cruel Treatment" No. 3477-IV of February 21, 2006.

Statistical processing of experimental data included calculations of arithmetic mean values $(M)$, their errors $( \pm m)$. Student's criterion (t) [13] was used to determine the probable difference between the mean values.

\section{Re sults and is cussion}

The optimal content of lidocaine hydrochloride in the composition of the semisolid drug being developed was determined by screening the local anesthetic activity of the gel test specimens containing $1.0 \%, 1.5 \%$ and $2.0 \%$ of the anesthetic.

Animals were divided into three groups: to animals of the 1st group was applied a gel 
with $2.0 \%$ concentration of lidocaine hydrochloride (sample No. 1), the second group with a concentration of $1.5 \%$ (sample No. 2), the third group - with 1.0\% lidocaine content (sample No. 3). The results of the study are shown in Table 1.

According to the results, pronounced pain syndrome was detected in animals of all three groups in 1 hour after the introduction of the phlogogenic agent.

Ta b le 1

Dynamics of analgesic activity of the gel test samples

\begin{tabular}{|c|c|c|c|c|c|c|}
\hline $\begin{array}{c}\text { Group, } \\
n=5\end{array}$ & $\begin{array}{c}\text { Statistic } \\
\text { indicator }\end{array}$ & $\begin{array}{c}\text { Initial } \\
\text { data }\end{array}$ & 1 hour & $\begin{array}{c}1 \mathrm{~h} \\
15 \mathrm{~min}\end{array}$ & $\begin{array}{c}1 \mathrm{~h} \\
30 \mathrm{~min}\end{array}$ & 2 hours \\
\hline \multirow[t]{4}{*}{ Test sample No. 1} & $M$ & 271.5 & 187.0 & 292.6 & 300.8 & 225.8 \\
\hline & $\pm m$ & 67.9 & 25.0 & 46.5 & 33.5 & 32.4 \\
\hline & $\%{ }^{1}$ & - & - & $+56.5 \% *$ & $+60.8 \% *$ & $+20.7 \%$ \\
\hline & $\% \%^{2}$ & - & $-30.9 \% *$ & $+7.1 \%$ & $+10.7 \%$ & $-16.9 \%$ \\
\hline \multirow{4}{*}{$\begin{array}{c}\text { Test sample } \\
\text { No. } 2\end{array}$} & $M$ & 235.4 & 209.6 & 294.6 & 273.8 & 234.2 \\
\hline & $\pm m$ & 42.8 & 21.2 & 57.4 & 17.9 & 35.5 \\
\hline & $\%^{1}$ & - & - & $+40.5 \% *$ & $+30.6 \% *$ & $+11.7 \%$ \\
\hline & $\% 0^{2}$ & - & $-11.1 \%$ & $+25.1 \%$ & $+16.2 \%$ & $-0.4 \%$ \\
\hline \multirow{4}{*}{$\begin{array}{c}\text { Test sample } \\
\text { No. } 3\end{array}$} & $M$ & 309.7 & 245.7 & 287.0 & 313.0 & 269.5 \\
\hline & $\pm m$ & 30.3 & 27.0 & 37.2 & 53.3 & 41.8 \\
\hline & $\%{ }^{1}$ & - & - & $+16.8 \%$ & $+27.4 \%$ & $+9.7 \%$ \\
\hline & $\%{ }^{2}$ & - & $-20.7 \%$ & $-7.1 \%$ & $+1.0 \%$ & $-12.9 \%$ \\
\hline
\end{tabular}

N o t e: ${ }^{1}$ - percentage change to the maximum of pain response;

${ }^{2}$ - percentage change to the initial level of tactile sensitivity;

$*-p \leq 0,05$.

According to the results of the study (Table 1), the use of the test sample No. 3 did not show a reliable antinociceptive effect and can be considered as a trend of analgesia. The pronounced local anesthetic effect was observed at application of test samples of gel No. 1 and No. 2 in 15 and 30 minutes and its duration was at least 2 hours. The use of gel in the concentration of $2.0 \%$ and $1.5 \%$ reduced the sensitivity of the inflamed paw in comparison with the initial value. At the same time, there were no reliable differences between the expressiveness of antinociceptive activity between samples of gel No. 1 and No. 2.

Moreover, analgetic activity of dental gel with a selected concentration of $1.5 \%$ lidocaine hydrochloride compared with foreign drug in gel form "Kamistad ${ }^{\mathbb{}}$ " (Stada Arzneimittel AG, Germany), which includes in its composition $2.0 \%$ of the anesthetic was studied. The results are shown in the Table 2.

$\mathrm{Tab} 1$ e 2

Results of analgesic activity study of test samples

\begin{tabular}{|c|c|c|c|c|c|c|}
\hline Sample & $\begin{array}{l}\text { Statistic } \\
\text { indicator }\end{array}$ & $\begin{array}{c}\text { Initial } \\
\text { data }\end{array}$ & 1 hour & $\begin{array}{c}1 \mathrm{~h} \\
15 \mathrm{~min}\end{array}$ & $\begin{array}{c}1 \mathrm{~h} \\
30 \mathrm{~min}\end{array}$ & 2 hours \\
\hline \multirow{4}{*}{$\begin{array}{l}\text { Developed dental gel } \\
n=5\end{array}$} & $M$ & 235.4 & 209.6 & 294.6 & 273.8 & 234.2 \\
\hline & $\pm m$ & 42.8 & 21.2 & 57.4 & 17.9 & 35.5 \\
\hline & $\%^{1}$ & - & - & $+40.5 \% *$ & $+30.6 \% *$ & $+11.7 \%$ \\
\hline & $\% \%^{2}$ & - & $-11.1 \%$ & $+25.1 \%$ & $+16.2 \%$ & $-0.4 \%$ \\
\hline \multirow{4}{*}{$\begin{array}{l}\text { Kamistad }^{\circledR} \\
n=5\end{array}$} & $M$ & 414.3 & 263.0 & 360.7 & 362.7 & 387.0 \\
\hline & $\pm m$ & 13.5 & 11.7 & 22,8 & 20.2 & 13.7 \\
\hline & $\%^{1}$ & - & - & $+36.8 \% *$ & $+37.9 \% *$ & $+47.1 \% *$ \\
\hline & $\% \%^{2}$ & - & $-36.5 \%$ & $-12.4 \%$ & $-12.5 \%$ & $-6.7 \%$ \\
\hline
\end{tabular}

$\mathrm{N}$ o t e: ${ }^{1}$ - percentage change to the maximum of pain response;

${ }^{2}$ - percentage change to the initial level of tactile sensitivity;

$*-p \leq 0,05$. 
According to the results of the study (Table 2), the developed dental gel on the model of kaolin edema revealed a pronounced local anesthetic effect - after 15 minutes, pain was reduced by $40.5 \%$ while using the reference drug "Kamistad ${ }^{\circledR}$ ", which contained in its composition a greater amount of lidocaine hydrochloride, - by $37 \%$. In addition, unlike the drug of comparison, in 1 hour after application, the study gel completely restored the initial pain threshold, that is, made complete anesthesia.

\section{Con c l u s i on s}

1. The test sample of gel No. 3 showed a weak tendency for the manifestation of analgesic activity, which may indicate a loss of analgesic activity with a decrease in the lidocaine content of up to $1.0 \%$ and serve as a justification for increasing the lidocaine hydrochloride concentration to $1.5 \%$.

2. Taking into account the fact that reliable statistical differences in the severity of analgesic activity between the test samples of gel No. 1 and No. 2 were not detected, it can be argued that the use of smaller $-1.5 \%$ lidocaine concentration in the composition of the developed drug is possible.

3. Despite the lower concentration of lidocaine in its composition $(1.5 \%)$ than in the reference drug $(2.0 \%)$, the claimed dental gel exceeds the reference medicine "Kamis$\operatorname{tad}^{\mathbb{}}$ " for the expressiveness of the antinociceptive effect immediately after application, and quickly restores the pain threshold, revealing reliable analgesic effect.

\section{Re f e r e n c e s}

1. Давтян Л. Л., Рева Д. В., Чубенко О. В., Трохимчук В. В. Розроблення методики виявлення та визначення діючих речовин у складі стоматологічного гелю // Фармац. журн. - 2016. - № 2. - С. 48-52.

2. Костригина Е. Д., Зюлькина Л. А., Иванов П. В. Современный взгляд на этиопатогенез пародонтита (обзор литературы) // Известия высших учебных заведений. Поволжский регион. Медицинские науки. - 2017. - № 3 (43). - C. 118-128. https://doi.org/10.21685/2072-3032-2017-3-13

3. Шманько В. В., Котик М. I., Микитів М. В. Сучасні підходи до лікування хвороб пародонта i слизової оболонки порожнини рота // Вісн. наукових досліджень. - 2015. - № 4. - С. 71-74. https://doi. org/10.11603/1681-276Х.2015.4.5649

4. Луцчкая И. К., Мартов В. Ю. Лекарственные средства в стоматологии: справочное издание. - М.: Медицинская литература, 2013. - 118 с.

5. Орехова Л. Ю., Кудрявиева Т. В., Бурлакова Ю. С. Системы локальной доставки лекарственных препаратов в пародонтологии // Пародонтология. - 2016. - № 1. - С. 34-39.

6. Заливская A. В., Жилякова E. T. Анализ основ стоматологических гелей для лечения гингивита // Сетевой журнал «Научный результат». Серия «Медицина и фармация». - 2016. - Т. 2, № 1 (7). - С. 53 58. https://doi.org/10.18413/2313-8955-2016-2-1-53-58

7. Рабинович С. А., Заводиленко Л. А. Системная токсичность местных анестетиков // Стоматология. - 2017. - № 96 (2). - C. 36-42. https://doi.org/10.17116/stomat201796236-42

8. Boyce R. A., Kirpalani T., Mohan N. Updates of Topical and Local Anesthesia Agents // Dent. Clin. North. Am. - 2016. - V. 60. - P. 445-471. https://doi.org/10.1016/j.cden.2015.12.001.

9. Hyo-Seol Lee. Recent advances in topical anesthesia // J. Dent. Anesth. Pain. Med. - 2016. - V. 16 (4). - P. 237-244. https://doi.org/10.17245/jdapm.2016.16.4.237

10. Wolf D., Otto J. Efficacy and Safety of a Lidocaine Gel in Patients from 6 Months up to 8 Years with Acute Painful Sites in the Oral Cavity: A Randomized, Placebo-Controlled, Double-Blind, Comparative Study // Int. J. Pediatr. - 2015. - P. 1-6. http://dx.doi.org/10.1155/2015/141767

11. Любомирский Г. Б., Любомирская Т. В., Любомирская Э. Г. Применение препарата Камистад в процессе ортодонтического лечения зубочелюстных аномалий в подростковом периоде // Стоматологпрактик. - 2013. - № 4. - С. 50-51.

12. Компендиум: лекарственные препараты. URL: httpHYPERLINK «http://compendium.com.ua/»:// HYPERLINK «http://compendium.com.ua/»compendiumHYPERLINK «http://compendium.com.ua/». HYPERLINK «http://compendium.com.ua/»comHYPERLINK «http://compendium.com.ua/».HYPERLINK «http://compendium.com.ua/»ua.

13. Стефанов О. В. Доклінічні дослідження лікарських засобів (Метод. рекомендації). - К.: Авіцена, 2001. $-528 \mathrm{c}$.

14. Directive 2010/63/EU of the European Parliament and of the Council of 22 September 2010 on the protection of animals used for scientific purposes // Official Journal of the European Union. - 2010. - L276. - P. 33-79. 


\section{R e f e r e n c e s}

1. Davtian L. L., Reva D. V., Chubenko O. V., Trokhymchuk V. V. Rozroblennia metodyky vyiavlennia ta vyznachennia diiuchykh rechovyn u skladi stomatolohichnoho heliu // Farmatsevtychnyi zh. - 2016. - № 2. - S. 48-52.

2. Kostrigina E. D., Zyulkina L. A., Ivanov P. V. Sovremennyiy vzglyad na etiopatogenez parodontita (obzor literaturyi) // Izvestiya vyisshih uchebnyih zavedeniy. Povolzhskiy region. Meditsinskie nauki. - 2017. № 3 (43). - S. 118-128. https://doi.org/10.21685/2072-3032-2017-3-13

3. Shmanko V. V., Kotyk M. I., Mykytiv M. V. Suchasni pidkhody do likuvannia khvorob parodonta i slyzovoi obolonky porozhnyny rota // Visnyk naukovykh doslidzhen. - 2015. - № 4. - S. 71-74. https://doi. org/10.11603/1681-276X.2015.4.5649

4. Lutskaya I. K., Martov V. Yu. Lekarstvennyie sredstva v stomatologii: spravochnoe izdanie. - M.: Meditsinskaya literatura, 2013. - $118 \mathrm{~s}$.

5. Orehova L. Yu., Kudryavtseva T. V., Burlakova Yu. S. Sistemyi lokalnoy dostavki lekarstvennyih preparatov v parodontologii // Parodontologiya. - 2016. - № 1. - S. 34-39.

6. Zalivskaya A. V., Zhilyakova E. T. Analiz osnov stomatologicheskih geley dlya lecheniya gingivita // Setevoy zhurnal «Nauchnyiy rezultat». Seriya «Meditsina i farmatsiya». - 2016. - T. 2, № 1 (7). - S. 53-58. https://doi.org/10.18413/2313-8955-2016-2-1-53-58

7. Rabinovich S. A., Zavodilenko L. A. Sistemnaya toksichnost mestnyih anestetikov // Stomatologiya. 2017. - № 96 (2). - S. 36-42. https://doi.org/10.17116/stomat201796236-42

8. Boyce R. A., Kirpalani T., Mohan N. Updates of Topical and Local Anesthesia Agents // Dent. Clin. North. Am. - 2016. - V. 60. - P. 445-471. https://doi.org/10.1016/j.cden.2015.12.001.

9. Hyo-Seol Lee. Recent advances in topical anesthesia // J. Dent. Anesth. Pain. Med. - 2016. - V. 16 (4). - P. 237-244. https://doi.org/10.17245/jdapm.2016.16.4.237

10. Wolf D., Otto J. Efficacy and Safety of a Lidocaine Gel in Patients from 6 Months up to 8 Years with Acute Painful Sites in the Oral Cavity: A Randomized, Placebo-Controlled, Double-Blind, Comparative Study // Int. J. Pediatr. - 2015. - P. 1-6. http://dx.doi.org/10.1155/2015/141767

11. Lyubomirskiy G. B., Lyubomirskaya T. V., Lyubomirskaya E. G. Primenenie preparata Kamistad v protsesse ortodonticheskogo lecheniya zubochelyustnyih anomaliy v podrostkovom periode // Stomatolog-praktik. - 2013. - № 4. - S. 50-51.

12. Kompendium: lekarstvennyie preparatyi. URL: httpHYPERLINK «http://compendium.com.ua/»:// HYPERLINK «http://compendium.com.ua/»compendiumHYPERLINK «http://compendium.com.ua/». HYPERLINK «http://compendium.com.ua/»comHYPERLINK «http://compendium.com.ua/».HYPERLINK «http://compendium.com.ua/»ua.

13. Stefanov O. V. Doklinichni doslidzhennia likarskykh zasobiv (Metod. rekomendatsii). - K.: Avitsena, 2001. - $528 \mathrm{~s}$.

14. Directive 2010/63/EU of the European Parliament and of the Council of 22 September 2010 on the protection of animals used for scientific purposes // Official Journal of the European Union. - 2010. - L276. - P. 33-79.

Надійшла до редакції 6 лютого 2019 р. Прийнято до друку 1 березня 2019 р.

Yu. S. Maslii ${ }^{1}$ (https://orcid.org/0000-0002-8968-0262),

O. O. Hrudnytska ${ }^{2}$ (https://orcid.org/0000-0002-8297-7119),

O. A. Ruban ${ }^{1}$ (https://orcid.org/0000-0002-2456-8210),

G. V. Zaychenko ${ }^{2}$ (https://orcid.org/ 0000-0002-3506-4800)

${ }^{1}$ National University of Pharmacy, Kharkiv

${ }^{2}$ Bogomolets National Medical University, Kyiv

JUSTIFICATION OF LOCAL ANESTHETIC AND CHOICE OF ITS CONCENTRATION IN

COMPOSITION OF DENTAL GEL

Key words: dental gel, lidocaine hydrochloride, local anaesthetic activity

A B S T R A C T

Dental diseases are often accompanied by painful sensations, so usually symptomatic treatment of these pathologies includes local anesthetics, as which we have selected anesthetic of local action - lidocaine hydrochloride.

The aim of the research is to substantiate the rational concentration of lidocaine hydrochloride in the composition of the dental gel being developed by pharmacological screening of its model samples.

The object of the study is dental gel with tincture "Phytodent" (PJSC "CPP "Red Star", Ukraine), choline salicylate $80 \%$ (Basf Pharma, Switzerland) and lidocaine hydrochloride (Societa Italiana Medicinali Scandicci, Italy). The anesthetic was injected into the gel at various concentrations $-1.0 \%, 1.5 \%$ and $2.0 \%$.

The study of local anesthetic/analgesic activity of gel test samples was performed by the Randall-Selitto method using an electronic Pressure Analgesiometer (IITC Life Science, USA). The study was conducted on male rats weighing 190-210 g. The animals were divided into three groups: animals of the 1st group were applied with $2.0 \%$ lidocaine hydrochloride gel (sample number 1), the second group - with $1.5 \%$ concentration (sample number 2), the third group - with 1.0\% lidocaine content (sample number 3 ). The animal was held in the 
hands of a researcher, its limb was placed in analgesiometer. Determined the force of pressure in grams, which causes the reaction of the paw pull back / squeal in response to a painful stimulus.

Analgesic activity was studied on the model of kaolin edema, which was simulated by sub-planar introduction of kaolin solution $(10 \mathrm{mg} / \mathrm{ml})$ in the amount of $0.1 \mathrm{ml} / 100$ grams of body weight (administration under the aponeurosis of the posterior paw).

In animals, the initial pain sensitivity was evaluated 1 hour after the introduction of the phlogogenic agent, after which the gel was applied to the foot, and in 1 hour 15 minutes, 1 hour 30 minutes and 2 hours after the exudative edema modelling. Calculated the percentage of change to the initial threshold of tactile sensitivity, as well as the percentage of change to the level of algesia (pain response) 1 hour after the introduction of the phlogogenic agent. Statistical processing of the data was performed using Student's t-criterion.

According to the results, pronounced pain syndrome was detected in animals of all three groups 1 hour after the introduction of the phlogogenic agent. The use of gel with $1.0 \%$ concentration of lidocaine hydrochloride did not show a significant antinociceptive effect and could be considered as a tendency for analgesia. The pronounced local anesthetic effect was observed with the use of gel test specimens with the anesthetic concentrations of $1.5 \%$ and $2.0 \%$ after 15 and 30 minutes and lasted for at least 2 hours. The drug developed was compared with the dental gel "Kamistad®" (Stada Arzneimittel AG, Germany), which also contains lidocaine hydrochloride in an amount of $2.0 \%$.

Taking into account the fact that reliable statistical differences in the severity of analgesic activity between the test samples of gel number 1 and number 2 were not detected, it can be argued that lower lidocaine concentration $1.5 \%$ in the composition of the developed dental gel can be used. In addition, the claimed dental gel exceeded the referent drug "Kamistad ${ }^{\mathbb{B}}$ " (Stada Arzneimittel AG, Germany) by the expressiveness of antinociceptive effect.

Ю. С. Маслій ${ }^{1}$ (https://orcid.org/0000-0002-8968-0262),

О. О. Грудницька ${ }^{2}$ (https://orcid.org/0000-0002-8297-7119),

О. А. Рубан ${ }^{1}$ (https://orcid.org/0000-0002-2456-8210),

Г. В. Зайченко ${ }^{2}$ (https://orcid.org/ 0000-0002-3506-4800)

${ }^{1}$ Національний фармацевтичний університет, м. Харків

${ }^{2}$ Національний медичний університет імені О. О. Богомольия, м. Київ

ОБГРУНТУВАННЯ АНЕСТЕТИКА МІСЦЕВОЇ ДІЇ ТА ВИБІР ЙОГО КОНЦЕНТРАЦІЇ У СКЛАДІ

СТОМАТОЛОГІЧНОГО ГЕЛЮ

Ключові слова: стоматологічний гель, лідокаїну гідрохлорид, місцевоанестезуюча активність

А Н О Т А Ц І Я

Стоматологічні захворювання часто супроводжуються больовими відчуттями, тому зазвичай симптоматичне лікування цих патологій включає місцеві знеболювальні засоби, як такий нами було обрано анестетик місцевої дії - лідокаїну гідрохлорид.

Метою досліджень $є$ обгрунтування раціональної концентрації лідокаїну гідрохлориду у складі стоматологічного гелю, що розробляється, шляхом проведення фармакологічного скринінгу його модельних зразків.

Об'єктом дослідження є стоматологічний гель з настойкою «Фітодент» (ПАТ «ХФЗ "Червона зірка"», Україна), холіну саліцилатом 80\% (Basf Pharma, Швейцарія) і лідокаїну гідрохлоридом (Societa Italiana Medicinali Scandicci, Італія). Анестетик вводили у гель в різних концентраціях - 1,0\%, 1,5\% та 2,0\%.

Вивчення місцевоанестезуючої/аналгетичної активності тест-зразків гелю проводили методом Randall-Selitto $з$ використанням електронного аналгезіметра Pressure Analgesiometer (IITC Life Science, США). Дослідження проведено на щурах-самцях масою 190-210 г. Тварини були розділені на три групи: тваринам 1-ої групи наносився гель із 2,0\% концентрацією лідокаїну гідрохлориду (зразок № 1), 2-ої групи - 3 1,5\% концентрацією (зразок № 2), 3-ої групи - 3 1,0\% вмістом лідокаїну (зразок № 3). Тварину фіксували в руках дослідника, іiі кінцівку вміщували в аналгезіметр. Визначали силу тиску в грамах, що спричинює реакцію відсмикування лапи/писк у відповідь на больовий подразник.

Аналгетичну активність вивчали на моделі каолінового набряку, яку моделювали шляхом субплантарного введення розчину каоліну (10 мг/мл) в кількості 0,1 мл/100 грам маси тіла (введення під апоневроз задньої лапи).

У тварин оцінювалася вихідна больова чутливість через 1 год після введення флогогенного агента, після цього був нанесений гель на лапку, і через 1 год 15 хв, 1 год 30 хв і 2 год після моделювання ексудативного набряку. Розраховували відсоток зміни до вихідного порогу тактильної чутливості, а також відсоток зміни до рівня альгезії (больової реакції) через 1 год після введення флогогенного агента. Статистичну обробку отриманих даних проводили з використанням t-критерію Стьюдента.

Згідно з отриманими результатами, виражений больовий синдром виявлявся у тварин всіх трьох груп через 1 год після введення флогогенного агента. Застосування гелю 3 1,0\% концентрацією лідокаїну гідрохлориду не виявило достовірного антиноцицептивного ефекту і може розглядатися як тенденція аналгезії. Виражений місцевоанестезуючий ефект відзначався при застосуванні тест-зразків 
гелю 3 концентрацією анестетика 1,5\% та 2,0\% через 15 і 30 хв і за тривалістю був не менше 2-х годин. Препарат, що розробляється, був порівняний зі стоматологічним гелем «Камістад ${ }^{\mathbb{R}}$ (Stada Arzneimittel $\mathrm{AG}$, Німеччина), який також містить в своєму складі лідокаїну гідрохлорид в кількості 2,0\%.

Враховуючи той факт, що достовірних статистичних відмінностей вираженості аналгетичної активності між тест-зразками гелю № 1 і № 2 не виявлено, можна стверджувати про можливість використання меншої - 1,5\% концентрації лідокаїну в складі стоматологічного гелю, що розробляється. Крім того, заявлений стоматологічний гель за виразністю антиноцицептивного ефекту перевершив референтний препарат «Камістад ${ }^{\circledR} »($ Stada Arzneimittel AG, Німеччина).

Ю. С. Маслий ${ }^{1}$ (https://orcid.org/0000-0002-8968-0262),

Е. О. Грудницкая ${ }^{2}$ (https://orcid.org/0000-0002-8297-7119),

Е. А. Рубан ${ }^{1}$ (https://orcid.org/0000-0002-2456-8210),

А. В. Зайченко ${ }^{2}$ (https://orcid.org/ 0000-0002-3506-4800)

${ }^{1}$ Национальный фармачевтический университет, г. Харьков

${ }^{2}$ Национальный медииинский университет имени А. А. Богомольйа, г. Киев

ОБОСНОВАНИЕ АНЕСТЕТИКА МЕСТНОГО ДЕЙСТВИЯ И ВЫБОР ЕГО КОНЦЕНТРАЦИИ В

СОСТАВЕ СТОМАТОЛОГИЧЕСКОГО ГЕЛЯ

Ключевые слова: стоматологический гель, лидокаина гидрохлорид, местноанестезирующая активность А Н Н О Т А ЦИ Я

Стоматологические заболевания часто сопровождаются болевыми ощущениями, поэтому обычно симптоматическое лечение этих патологий включает местные обезболивающие средства, в качестве которого нами был выбран анестетик местного действия - лидокаина гидрохлорид.

Целью исследований является обоснование рациональной концентрации лидокаина гидрохлорида в составе разрабатываемого стоматологического геля путем проведения фармакологического скрининга его модельных образцов.

Объектом исследования является стоматологический гель с настойкой «Фитодент» (ПАО «ХФЗ "Красная звезда"», Украина), холина салицилатом 80\% (Basf Pharma, Швейцария) и лидокаина гидрохлоридом (Societa Italiana Medicinali Scandicci, Италия). Анестетик вводили в гель в разных концентрациях $-1,0 \%, 1,5 \%$ и $2,0 \%$.

Изучение местноанестезирующей/анальгетической активности тест-образцов геля проводили методом Randall-Selitto с использованием электронного анальгезиметра Pressure Analgesiometer (IITC Life Science, США). Исследование проведено на крысах-самцах массой 190-210 г. Животные были разделены на три группы: животным первой группы наносился гель с 2,0\% концентрацией лидокаина гидрохлорида (образец № 1), второй группы - с 1,5\% концентрацией (образец № 2), 3-й группы - с 1,0\% содержанием лидокаина (образец № 3). Животное фиксировали в руках исследователя, его лапку помещали в анальгезиметр. Определяли силу давления в граммах, вызывающую реакцию отдергивания лапы/писк в ответ на болевой раздражитель.

Анальгетическую активность изучали на модели каолинового отека, которую моделировали путем субплантарного введения раствора каолина (10 мг/мл) в количестве 0,1 мл/100 грамм массы тела (введение под апоневроз задней лапы).

У животных оценивали исходную болевая чувствительность через 1 ч после введения флогогенного агента, после этого был нанесен гель на лапку, и вновь фиксировали порог болевой чувствительности через 1 час 15 мин, 1 час 30 мин и 2 часа после моделирования экссудативного отека. Рассчитывали процент изменения к исходному порогу тактильной чувствительности, а также процент изменения до уровня альгезии (болевой реакции) через 1 ч после введения флогогенного агента. Статистическую обработку полученных данных проводили с использованием t-критерия Стьюдента.

Согласно полученным результатам, выраженный болевой синдром проявлялся у животных всех трех групп через 1 ч после введения флогогенного агента. Применение геля с 1,0\% концентрацией лидокаина гидрохлорида не выявило достоверного антиноцицептивного эффекта и может рассматриваться как тенденция анальгезии. Выраженный местноанестезирующий эффект отмечался при применении тест-образцов геля с концентрацией анестетика $1,5 \%$ и 2,0\% через 15 и 30 мин и по продолжительности был не менее 2-х часов. Разрабатываемый препарат сравнивали со стоматологическим гелем «Камистад ${ }^{\mathbb{R}}$ » (Stada Arzneimittel AG, Гepмания), который также содержит в своем составе лидокаина гидрохлорид в количестве 2,0\%.

Учитывая тот факт, что достоверных статистических различий выраженности анальгетической активности между тест-образцами геля № 1 и № 2 не обнаружено, можно утверждать о возможности использования меньшей - 1,5\% концентрации лидокаина в составе разрабатываемого стоматологического геля. Кроме того, заявленный стоматологический гель по выраженности антиноцицептивного эффекта превзошел референтный препарат «Камистад ${ }^{\mathbb{E}} »$ (Stada Arzneimittel AG, Германия).

\section{Електронна адреса для листування завторами: julia.masliy@gmail.com}

